Article

\title{
Polymer Inclusion Membranes (PIMs) Doped with Alkylimidazole and their Application in the Separation of Non-Ferrous Metal Ions
}

\author{
Elzbieta Radzyminska-Lenarcik ${ }^{1, *(1)}$ and Malgorzata Ulewicz ${ }^{2}$ (1) \\ 1 Faculty of Chemical Technology and Engineering, UTP University of Science and Technology, Seminaryjna 3, \\ PL 85-326 Bydgoszcz, Poland \\ 2 Czestochowa University of Technology, Dabrowskiego 69 Street, PL 42-201 Czestochowa, Poland; \\ ulewicz@bud.pcz.pl \\ * Correspondence: elaradz@utp.edu.pl
}

Received: 24 September 2019; Accepted: 28 October 2019; Published: 30 October 2019

\begin{abstract}
The study involved the transport of zinc(II), cadmium(II), and nickel(II) ions from acidic aqueous solutions using polymer inclusion membranes (PIMs). PIMs consisted of cellulose triacetate (CTA) as a support; o-nitrophenyl pentyl ether (o-NPPE) as a plasticizer; and 1-octylimidazole (1) 1-octyl-2-methylimidazole (2), 1-octyl-4-methylimidazole (3), or 1-octyl-2,4-dimethylimidazole (4) as ion carriers. The membranes were characterized by means of atomic force microscopy (AFM) and scanning electron microscopy (SEM). The results show that $\mathrm{Zn}(\mathrm{II})$ and $\mathrm{Cd}(\mathrm{II})$ are effectively transported across PIMs, while Ni(II) transport is not effective. The rate of transport of metal ions across PIMs is determined by the diffusion rate of the $\mathrm{M}(\mathrm{II})$-carrier complex across the membrane. The best result achieved for $\mathrm{Zn}$ (II) removal after $24 \mathrm{~h}$ was $95.5 \%$ for the ternary $\mathrm{Zn}(\mathrm{II})-\mathrm{Cd}(\mathrm{II})-\mathrm{Ni}$ (II) solution for PIM doped (4). For this membrane, the separation coefficients for $\mathrm{Zn}(\mathrm{II}) / \mathrm{Cd}(\mathrm{II}), \mathrm{Zn}(\mathrm{II}) / \mathrm{Ni}(\mathrm{II})$, and $\mathrm{Cd}(\mathrm{II}) / \mathrm{Ni}(\mathrm{II})$ were $2.8,104.5$, and 23.5, respectively. Additionally, the influence of basicity and structure of carrier molecules on transport kinetics was discussed.
\end{abstract}

Keywords: polymer inclusion membrane; metal separation; imidazole derivatives

\section{Introduction}

Zinc, cadmium, and nickel are among the most commonly used metals in industries. Due to their wide application, zinc, nickel, and cadmium are classified as strategic metals [1,2]. They are used in various branches of industry and in new fields of technology. The wide industrial use of those metals causes the generation of metal-bearing wastes in the form of sewage, dust, sludge, waste heaps, etc. [3-5]. An increasing interest in and consumption of these metals results in an increase of their prices, as well as a growing interest even in poor raw materials for their production. Therefore, the metal bearing waste has become an increasingly demanded raw material, and methods for reclaiming waste from industrial waste are steadily gaining in importance. During the last fifty years, solvent extraction has been a technique widely used for the processing of metal-bearing poor raw materials [6-9].

This technique has frequently been used in the extraction of some non-ferrous metals [10-17]. An increasing demand for metal production has led to the search for more efficient and economical methods required by the industry for purification of wastes. Membrane technologies have become an important alternative to conventional processes employed for wastewater treatment, and separation and recovery of target metals [17-21]. The selective transport of metal ions has been widely studied with supported (SLMs) and polymer inclusion (PIMs) liquid membranes [22-33]. Their high selectivity, high diffusion rates, and the possibility to concentrate ions have made them particularly useful [20,34]. 
The microstructure of the membrane surface is one of the important aspects influencing the process of metal ions separation. The supported liquid membranes (SMLs) are characterized by a structure strictly determined by the use of the specific polymer film (e.g., polyamide, Teflon). The commercially available membrane sheets (e.g., Celgard 2400, Accurel, Goretex) have precisely defined parameters, i.e., thickness, porosity, pore size, or curvature. In the case of polymer inclusion membranes (PIMs), formed by the pouring of a polymer, plasticizer, and carrier solution, the structure of the formed membrane differs, depending on the type and concentration of the substances. Therefore, it is necessary to examine the microstructure of the membrane material surface to determine basic parameters, such as the carrier distribution in the polymer matrix, or surface porosity and roughness. To this date, only a few studies [35-42] on the membrane morphology have been published. Amongst various techniques for examining surfaces, scanning electron microscopy (SEM) and atomic force microscopy (AFM) are the most useful and commonly used for this purpose.

Recently, PIMs have also been examined for their thermal stability [36,41,43]. For this purpose, they undergo a thermal analysis to determine thermal stability of polymers and to specify temperature ranges and thermal effects of their thermal degradation. The aim of this work was to check the possibility of separation and recovery of $\mathrm{Zn}$ (II) from mixtures of $\mathrm{Zn}(\mathrm{II})-\mathrm{Cd}(\mathrm{II})-\mathrm{Ni}(\mathrm{II})$ ions in aqueous solutions, using PIMs. For this purpose, alkyl derivatives of imidazole with small alkyl groups close to the donor nitrogen have influence on the complex formation, and the large alkyl substituent in the 1-position ensures the hydrophobicity of the molecule, selected as a carrier in PIMs. In the discussed case, 1-octylimidazole, 1-octyl-2-methylimidazole, 1-octyl-4-methylimidazole, and 1-octyl-2,4-dimethylimidazole were used as carriers. It was assumed that by different formation of the zinc, cadmium, and nickel ions complexes based on the above properties, it would be possible to diversify their properties, thus enabling their separation.

\section{Experimental}

\subsection{Reagents}

Analytical grade chemical reagents including zinc(II), cadmium(II), and nickel(II) nitrates; sulphuric acid; and tetramethylammonium hydroxide were purchased from (POCh, Gliwice, Poland). All aqueous solutions were prepared using analytical reagent grade chemicals and deionized water (conductivity, $0.10 \mu \mathrm{S} / \mathrm{cm}$ ). Solutions of $\mathrm{Zn}$ (II) and $\mathrm{Cd}(\mathrm{II})$ were prepared by dissolving appropriate amounts of $\mathrm{Zn}\left(\mathrm{NO}_{3}\right)_{2} \cdot 6 \mathrm{H}_{2} \mathrm{O}, \mathrm{Cd}\left(\mathrm{NO}_{3}\right)_{2} \cdot 4 \mathrm{H}_{2} \mathrm{O}$, and $\mathrm{Ni}\left(\mathrm{NO}_{3}\right)_{2} \cdot 6 \mathrm{H}_{2} \mathrm{O}$ in deionized water.

Analytical grade organic reagents, i.e., cellulose triacetate (CTA), o-nitrophenyl pentyl ether (o-NPPE), and dichloromethane (all from Sigma-Aldrich Company, Poznan, Poland) were used without further purification. The compounds 1-octylimidazole (1) $)$ 1-octyl-2-methylimidazole (2), 1-octyl-4-methylimidazole (3), and 1-octyl-2,4-dimethylimidazole (ㅁ) (Figure 1) were synthesized according to the procedure described in [44] by the alkylation of imidazole (Sigma-Aldrich Company, Poznan, Poland), 2-methylimidazole (Sigma-Aldrich Company, Poznan, Poland), 4-methylimidazole (Sigma-Aldrich Company, Poznan, Poland), and 2,4-dimethylimidazole (Sigma-Aldrich Company, Poznan, Poland) n-octyl bromide (ICP Industrial Product, Beer Sheva, Israel) in yields amounting to $78 \%, 65 \%, 63 \%$, and $68 \%$, respectively [45]. 
<smiles>CCCn1ccnc1</smiles><smiles>CCCn1ccnc1C</smiles>

b.p. $115-117^{\circ} \mathrm{C} / 2 \mathrm{~mm}$

$\mathrm{Hg}$

$\mathrm{pKa}=7.34[45]$

$\underline{1}$
b.p. $106-108^{\circ} \mathrm{C} / 14 \mathrm{~mm}$
$\mathrm{Hg}$
$\mathrm{pKa}=8.40[45]$
$\underline{2}$<smiles>CCCn1cnc(C)c1</smiles>
b.p. $144-146{ }^{\circ} \mathrm{C} / 10$
$\mathrm{mmHg}$
$\mathrm{pKa}=8.10$ [45]
$\underline{3}$

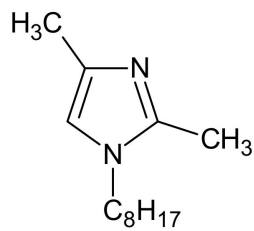

b.p. $160-163{ }^{\circ} \mathrm{C} / 10 \mathrm{~mm}$

$\mathrm{Hg}$

$\mathrm{pKa}=9.03$ [45]

$\underline{4}$

Figure 1. The chemical formula of alkylimidazole.

The carrier's structure was confirmed by $1 \mathrm{H}$ NMR (400 MHz,), $13 \mathrm{C} \mathrm{NMR} \mathrm{(100.6} \mathrm{MHz),} \mathrm{and} \mathrm{15N}$ NMR (40 MHz,) spectroscopy (Brucker, Hanau Germany).

1: ${ }^{1} \mathrm{H}$ NMR, $\mathrm{CDCl}_{3}, \delta(\mathrm{ppm}): 0.821\left(\mathrm{t}, 3 \mathrm{H}, \mathrm{C}-\mathrm{CH}_{3}\right), 1.259\left(\mathrm{~m}, 6 \mathrm{H}, \mathrm{C}-\left(\mathrm{CH}_{2}\right)_{3}-\mathrm{C}\right), 1.671(\mathrm{~m}, 6 \mathrm{H}$, $\left.\mathrm{C}-\left(\overline{\mathrm{CH}}_{2}\right)_{3}-\mathrm{C}\right), 3.829\left(\mathrm{t}, 2 \mathrm{H}, \mathrm{CH}_{2}-\mathrm{N}^{1}\right), 7.378\left(\mathrm{~s}, 1 \mathrm{H},{ }^{2} \mathrm{CH}\right), 6.955\left(\mathrm{~s}, 1 \mathrm{H},{ }^{4} \mathrm{CH}\right), 6.819\left(\mathrm{~s}, 1 \mathrm{H},{ }^{5} \mathrm{CH}\right) ;{ }^{13} \mathrm{C}$ $\mathrm{NMR}, \mathrm{CDCl}_{3}, \delta(\mathrm{ppm}): 13.925,22.804,26.500,28.948,29.253,31.699,39.556,46.712,115.251,129.353$, 135.970; ${ }^{15} \mathrm{~N} \mathrm{NMR} \mathrm{CDCl}_{3}, \delta$ (ppm): 256.34, 173.47 .

2: ${ }^{1} \mathrm{H}$ NMR, $\mathrm{CDCl}_{3}, \delta(\mathrm{ppm}): 0.781\left(\mathrm{t}, 3 \mathrm{H}, \mathrm{C}-\mathrm{CH}_{3}\right), 1.808\left(\mathrm{~m}, 6 \mathrm{H}, \mathrm{C}-\left(\mathrm{CH}_{2}\right)_{3}-\mathrm{C}\right), 1.742(\mathrm{~m}, 6 \mathrm{H}$, $\left.\mathrm{C}-\left(\mathrm{CH}_{2}\right)_{3}-\mathrm{C}\right), 3.823\left(\mathrm{t}, 2 \mathrm{H}, \mathrm{CH}_{2}-\mathrm{N}^{1}\right), 2.398\left(\mathrm{~s}, 3 \mathrm{H},{ }^{2} \mathrm{C}-\mathrm{CH}_{3}\right), 6.808\left(\mathrm{~s}, 1 \mathrm{H},{ }^{5} \mathrm{CH}\right), 7.005\left(\mathrm{~s}, 1 \mathrm{H},{ }^{4} \mathrm{CH}\right)$; ${ }^{13} \mathrm{C} \mathrm{NMR} \mathrm{CDCl}_{3}, \delta$ (ppm): 13.998, 22.554, 26.523, 28.991, 29.045, 31.045, 31.679, 32.025, 47.019, 118.740, 129.303, 137.019; ${ }^{15} \mathrm{~N} \mathrm{NMR} \mathrm{CDCl}_{3}, \delta(\mathrm{ppm}): 255.13,173.82$.

3: ${ }^{1} \mathrm{H}$ NMR, $\mathrm{CDCl}_{3}, \delta(\mathrm{ppm}): 0.810\left(\mathrm{t}, 3 \mathrm{H}, \mathrm{C}-\mathrm{CH}_{3}\right), 1.258\left(\mathrm{~m}, 6 \mathrm{H}, \mathrm{C}-\left(\mathrm{CH}_{2}\right)_{3}-\mathrm{C}\right), 1.691(\mathrm{~m}, 6 \mathrm{H}$, $\left.\mathrm{C}-\left(\mathrm{CH}_{2}\right)_{3}-\mathrm{C}\right), 3.764\left(\mathrm{t}, 2 \mathrm{H}, \mathrm{CH}_{2}-\mathrm{N}^{1}\right), 2.249\left(\mathrm{~s}, 3 \mathrm{H},{ }^{4} \mathrm{C}-\mathrm{CH} 3\right), 6.733\left(\mathrm{~s}, 1 \mathrm{H},{ }^{5} \mathrm{CH}\right), 6.580\left(\mathrm{~s}, 1 \mathrm{H},{ }^{2} \mathrm{CH}\right) ;{ }^{13} \mathrm{C}$ $\mathrm{NMR}, \mathrm{CDCl}_{3}, \delta$ (ppm): 13.937, 22.496, 26.463, 28.989, 29.083, 31.632, 38.556, 46.892, 117.961, 126.959, 136.522; ${ }^{15} \mathrm{~N} \mathrm{NMR} \mathrm{CDCl}_{3}, \delta(\mathrm{ppm}): 256.68,174.61$.

4: ${ }^{1} \mathrm{H} \mathrm{NMR}, \mathrm{CDCl}_{3}, \delta(\mathrm{ppm}): 0.775\left(\mathrm{t}, 3 \mathrm{H}, \mathrm{C}-\mathrm{CH}_{3}\right), 1.607\left(\mathrm{~m}, 6 \mathrm{H}, \mathrm{C}-\left(\mathrm{CH}_{2}\right)_{3}-\mathrm{C}\right), 1.945(\mathrm{~m}, 6 \mathrm{H}$, $\left.\mathrm{C}-\left(\mathrm{CH}_{2}\right)_{3}-\mathrm{C}\right), 3.811\left(\mathrm{t}, 2 \mathrm{H}, \mathrm{CH}_{2}-\mathrm{N}^{1}\right), 2.249\left(\mathrm{~s}, 3 \mathrm{H},{ }^{2} \mathrm{C}^{-} \mathrm{CH}_{3}\right), 6.642\left(\mathrm{~s}, 1 \mathrm{H},{ }^{5} \mathrm{CH}\right), 7.608\left(\mathrm{~s}, 3 \mathrm{H},{ }^{4} \mathrm{C}-\mathrm{CH}_{3}\right)$; ${ }^{13} \mathrm{C} \mathrm{NMR} \mathrm{CDCl}_{3}, \delta$ (ppm): 13.712, 22.414, 26.603, 27.882, 29.009, 30.925, 32.071, 39.556, 46.854, 47.262, $115.251,128.969,137.543 ;{ }^{15} \mathrm{~N} \mathrm{NMR} \mathrm{CDCl}_{3}, \delta$ (ppm): 255.76, 172.63 .

The Preparation and Characteristics of Polymer Inclusion Membranes

The concentration of the ion carrier in the membrane was $60 \%$, since earlier studies $[22,23,26,29,30,42,46]$ indicate that this concentration is optimum for that group of carriers.

The polymer membranes were prepared according to the procedure reported in our previous papers $[22,23,26,29,30,42,46-48]$. Organic solutions of the $35 \%$ support (CTA), the $60 \%$ ion carrier (1-4), and 5\% the plasticizer (o-nitrophenylpentyl ether (o-NPPE)) solutions in dichloromethane were prepared. A portion of such a solution was poured into a membrane mold comprised of a $6.0 \mathrm{~cm}$ glass ring attached to a glass plate with CTA-dichloromethane glue. The organic solvent was allowed to evaporate overnight and the resulting membrane was separated from the glass plate by immersion in cold water.

The thickness of the PIM was measured using a digital micrometer (Panametrics ${ }^{\circledR}$ Magna-Mike ${ }^{\circledR}$ 8500 (San Diego, CA, USA)) with an accuracy of $0.1 \mu \mathrm{m}$. The thickness of a membrane was measured 10 times for each case and shown as the average value of these measurements, with the standard deviation below $1 \%$. The thickness of membranes before and after transport was found to be the same. The average PIM thickness varied in the range 29-33 $\mu \mathrm{m}$.

Each experiential point was repeated 4 times, i.e., membrane formed by immobilization, thickness measured, and transport parameters calculated. Experimental reproducibility was high with standard deviation below $1 \%$ of the measured values. 
A surface characterization study of the polymer membranes was performed using an Atomic-force MultiMode Scanning Probe Microscope IIIa (AFM) (Digital Instruments Vecco Metrology Group, Santa Barbara, CA, USA) according to the procedure described in other papers [49-51]. Pore characterization was performed using the AFM image processing program NanoScope v.5.12, which enabled the calculation of two parameters: roughness $\left(\mathrm{R}_{\mathrm{q}}\right)$ and porosity $(\varepsilon)$. The $\mathrm{R}_{\mathrm{q}}$ parameter is the standard deviation of the $\mathrm{z}$ values within the box cursor and is calculated as:

$$
\mathrm{R}_{\mathrm{q}}=\sqrt{\frac{\sum\left(\mathrm{z}_{\mathrm{i}}\right)^{2}}{\mathrm{n}}}
$$

Additionally, the PIMs were characterized by scanning electron microscopy (SEM). SEM images of membranes were obtained with a Hitachi SU 3500 SEM/EDS (energy dispersive spectroscopy) microscope operated at $10.0 \mathrm{kV}$. The membranes were visualized in $5.0 \times 5.0 \mu \mathrm{m}$ images.

\subsection{Transport Studies}

Transport experiments were carried out in a permeation cell described in earlier papers $[22,23,26,29,30,42,46-48]$. The membrane film (surface area $4.9 \mathrm{~cm}^{2}$ ) was tightly clamped between two cell compartments. Both, the source phase and the receiving aqueous phase $\left(45 \mathrm{~cm}^{3}\right.$ each) were mechanically stirred at $600 \mathrm{rpm}$. Metal nitrates were used in the source phase, whereas the receiving phase was $0.5 \mathrm{M}$ solution of sulphuric acid. The PIM transport experiments were carried out at $20 \pm 0.2^{\circ} \mathrm{C}$. Small samples of the aqueous receiving phase were taken periodically from the sampling port equipped with a syringe and analyzed by atomic absorption spectroscopy (AAS 240FS Spectrometer, Agilent, Santa Clara, CA, USA) to determine zinc(II), cadmium(II), and nickel(II) concentrations. The $\mathrm{pH}$ of the source phase equal to 5.8 was kept constant using tetramethylammonium hydroxide.

The kinetics of transport across PIMs was described as a first-order process with respect to the metal-ion concentration [52] expressed by Equation (2):

$$
\ln \left(\frac{\mathrm{c}}{\mathrm{c}_{\mathrm{i}}}\right)=-\mathrm{kt}
$$

In order to calculate the value of $k, \ln \left(c / c_{0}\right)$ versus time was plotted. The rate constant values for two independent transport experiments were averaged, and the standard deviation was calculated. The permeability coefficient $(\mathrm{P})$ was calculated according to Equation (3):

$$
\mathrm{P}=-\frac{\mathrm{V}}{\mathrm{A}} \mathrm{k}
$$

The initial flux $\left(\mathrm{J}_{0}\right)$ was calculated as:

$$
\mathrm{J}_{\mathrm{i}}=\mathrm{P} \cdot \mathrm{C}_{\mathrm{i}}
$$

The selectivity ratio (S) was defined as the ratio of initial fluxes for $\mathrm{M}_{1}$ and $\mathrm{M}_{2}$ metal ions, respectively:

$$
\mathrm{S}=\mathrm{J}_{\mathrm{i}, \mathrm{M} 1} / \mathrm{J}_{\mathrm{i}, \mathrm{M} 2}
$$

In order to describe the efficiency of metal removal from the source phase, the recovery factor (RF) was calculated:

$$
\mathrm{RF}=\frac{\mathrm{c}_{\mathrm{i}}-\mathrm{c}}{\mathrm{c}_{\mathrm{i}}} \cdot 100 \%
$$

The reported values correspond to the average values of three replicates, with deviations within $5 \%$. 


\section{Results and Discussion}

\subsection{Membrane Characterization}

The SEM photomicrographs (Figure 2) showed that all membranes had dense and homogeneous structures. Moreover, the images showed visible roughness of film surfaces. Carriers could crystallize in the membrane and, for example, alkylimidazole molecules migrated to the membrane surface, causing its roughness and porosity.

1
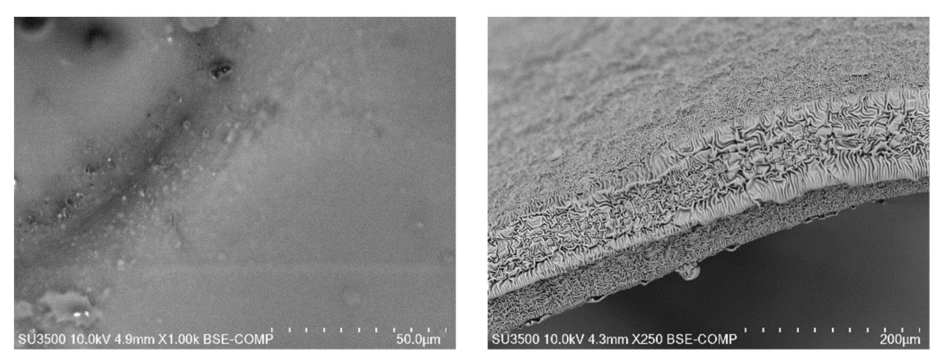

$\underline{2}$
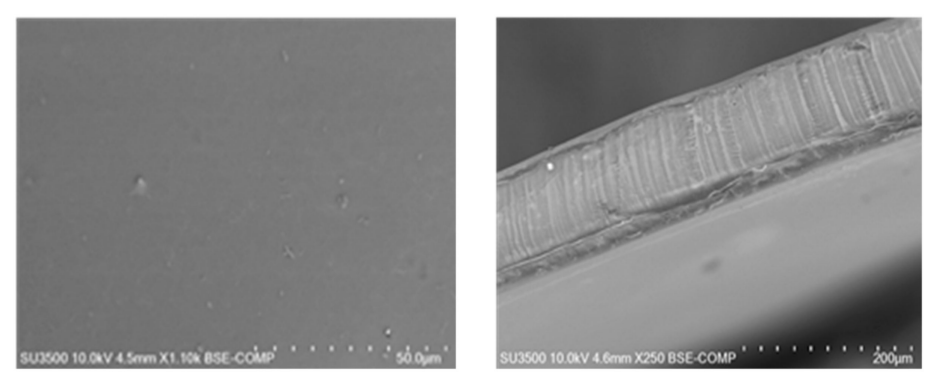

$\underline{\mathbf{3}}$
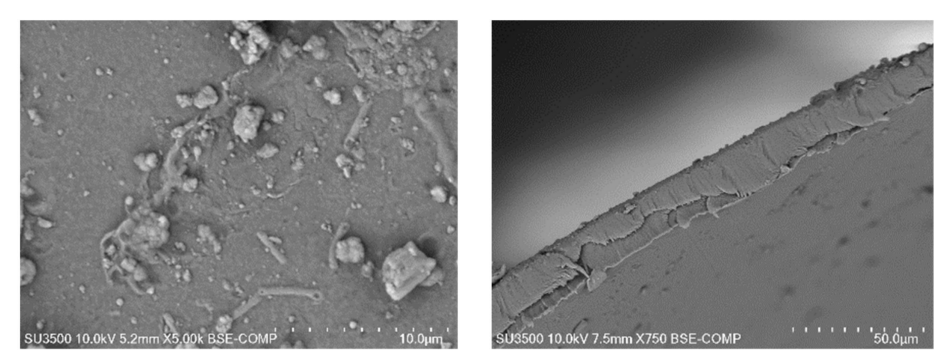

$\underline{4}$

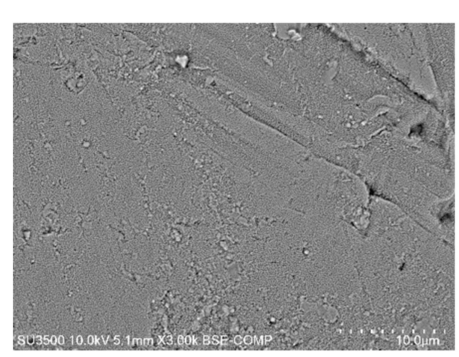

a)

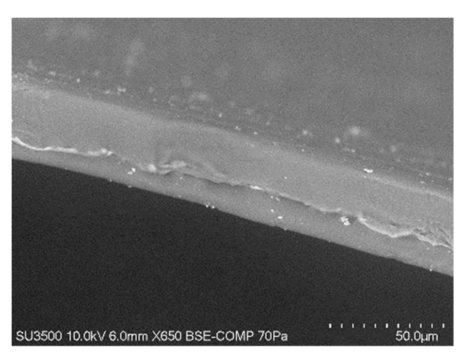

b)

Figure 2. SEM images of polymer inclusion membranes (PIMs) containing 1-octylimidazole (1), 1-octyl-2-methylimidazole (2), 1-octyl-4-methylimidazole (3), and 1-octyl-2,4-dimethylimidazole (4) as a carrier: front view (a), cross-section along the diameter $(\mathbf{b})$. 
The distribution of the carrier in the investigated membrane after the evaporation of

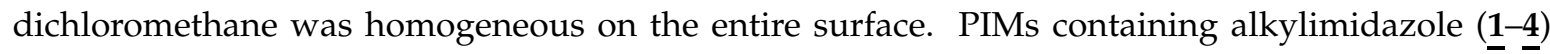
were dense and homogenous.

An AFM image of the PIM doped with alkylimidazole (1-4) in two-dimensional forms is shown in Figure 3.
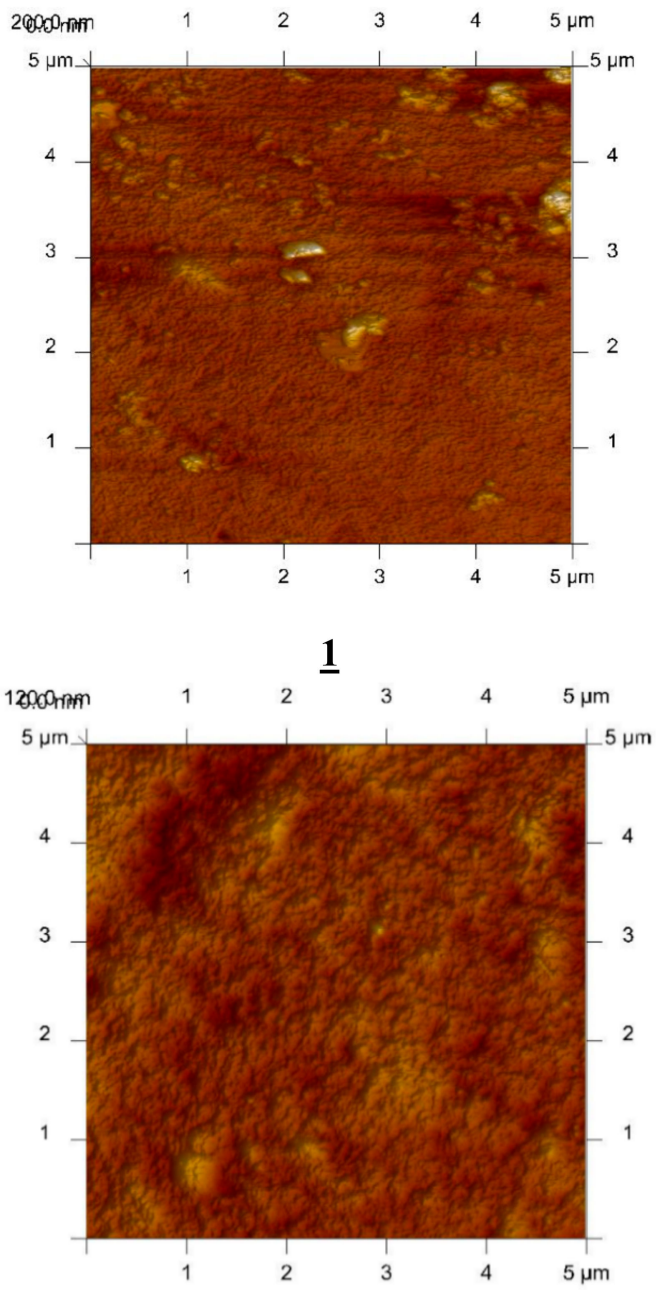

$\underline{\mathbf{3}}$

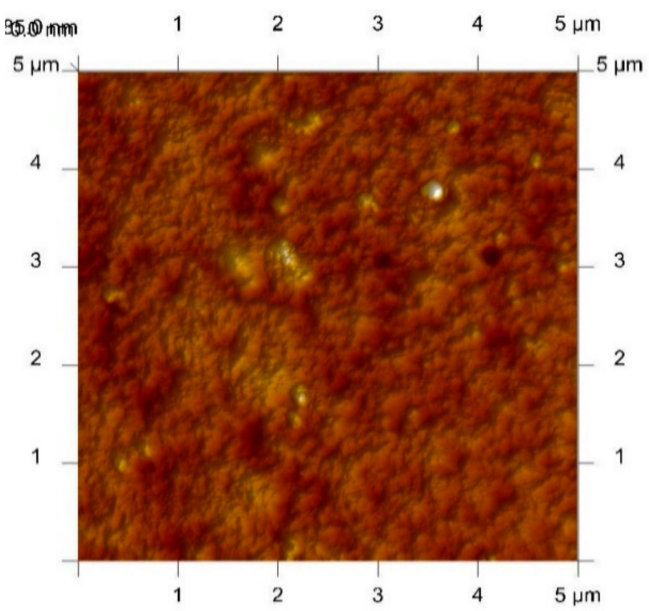

$\underline{2}$

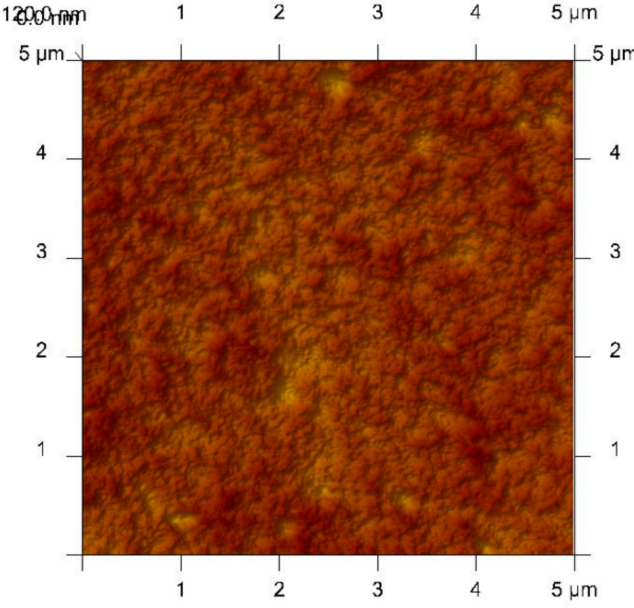

$\underline{4}$

Figure 3. 2D-view atomic force micrographs (AFMs) of PIMs with 1-octylimidazole (1), 1-octyl-2-methylimidazole (2), 1-octyl-4-methylimidazole (3), and 1-octyl-2,4-dimethylimidazole (4), at a $60 \%$ carrier concentration. Scan area: $5 \times 5 \mu \mathrm{m}$.

In the image of the PIM samples (Figure 3), clearly visible are elongated pores called also "cavity channels" (darker regions). Such a morphology of the membrane surface can be related to the crystallinity of the CTA. A wide network of pores of $5-25 \mathrm{~nm}$ in size is likely to be responsible for the improved transport performance of the membranes.

The roughness $\left(\mathrm{R}_{\mathrm{q}}\right)$ and effective pore sizes of the membrane were calculated using atomic force microscopy (AFM), and they are shown in Table 1 along with the data of membranes doped with 1-decyl-2-methylimidazole [30], 1-decyl-4-methylimidazole [26], and 1-decyl-2,4-dimethylimidazole [53]. 
Table 1. AFM characterization parameters for PIMs doped with alkylimidazoles. CTA-O-NPPE is cellulose triacetate-o-nitrophenyl pentyl ether.

\begin{tabular}{|c|c|c|c|c|}
\hline $\begin{array}{c}\text { Carrier in the CTA-o-NPPE } \\
\text { Membrane }\end{array}$ & $\begin{array}{l}\text { Effective Pore Size } \\
\qquad(\mu \mathrm{m})\end{array}$ & Tortuosity & $\underset{(\mathrm{nm})}{\operatorname{Roughness}\left(\mathrm{R}_{\mathrm{q}}\right)}$ & Ref. \\
\hline 1-decyl-2-methylimidazole & 0.057 & 2.81 & 7.2 & [30] \\
\hline 1-decyl-4-methylimidazole & 0.060 & 2.85 & 6.7 & [26] \\
\hline 1-decyl-2,4-dimethylimidazole & 0.065 & 2.45 & 5.8 & [53] \\
\hline 1-octylimidazole $(\underline{\mathbf{1}})$ & 0.051 & 2.15 & 5.4 & this work \\
\hline 1-octyl-2-methylimidazole (2) & 0.054 & 2.38 & 6.1 & this work \\
\hline 1-octyl-4-methylimidazole $(\overline{3})$ & 0.058 & 2.75 & 6.5 & this work \\
\hline 1-octyl-2,4-dimethylimidazole $(\underline{4})$ & 0.062 & 2.60 & 6.0 & this work \\
\hline
\end{tabular}

The membrane's tortuosity was determined from the dependence developed by Wolf and Strieder [54]:

$$
\tau=1-\ln \varepsilon
$$

As demonstrated in a number of papers [40,41,49-51], the microstructure of the membrane has an impact on the transport process. CTA membranes have porous structures, and the distribution of pores is nearly uniform (porosity 50\%) [52]. The pores in a CTA matrix are filled with a plasticizer (o-NPPE) and the carrier. The carrier crystallizes inside the membrane, with the texture of the surface being relatively homogeneous, with different porosities and roughnesses. The roughness of a CTA membrane obtained by Tor et al. [51] equaled $14 \mathrm{~nm}$, whereas the roughness of a CTA-o-NPPE membrane obtained by Radzyminska-Lenarcik and Ulewicz [47] equaled $6.8 \mathrm{~nm}$. As seen in Table 1, the roughness of polymer inclusion membranes decrease in the sequence $3>2>4>1$. For the tested carriers, no relationship was observed between the roughness of the membrane and the molar intrinsic volumes of the tested carriers, as was previously observed when the derivatives of imidazole azothiacrown ethers [49] were used. Nevertheless, the membranes with 1-octyl-alkyl derivatives of imidazole had lower molar intrinsic volumes and showed lower roughness than membranes with 1-decyl-alkyl derivatives of imidazole used in papers [26,30,53], which had larger molar intrinsic volumes. The roughness values determined for polymer inclusion membranes with carriers $\underline{\mathbf{1}} \mathbf{-} \underline{\mathbf{4}}$ were insignificantly higher than for the commercial di-(2-ethylhexyl) phosphoric acid (D2EHPA) carrier $(4.7 \mathrm{~nm})$ used by Salazar-Alvarez [50].

\subsection{Transport $\mathrm{Zn}(I I), \mathrm{Cd}(\mathrm{II})$, and Ni(II) across PIMs}

Findings on the transport of non-ferrous metal ions from equimolar nitrate solutions, across PIMs containing 1-octylimidazole (1) , 1-octyl-2-methylimidazole (2), 1-octyl-4-methylimidazole (3), and 1-octyl-2,4-dimethylimidazole (4) as ion carriers are discussed below. The studies were carried out from single- or multi-component solutions, containing metals each at a concentration of $0.001 \mathrm{M}$. The initial flux values and selectivity coefficients for the metal ion transport across the PIMs are shown in Table 2.

It follows from the data shown in Table 2 that the initial flux value for $\mathrm{Zn}$ (II) ion transport from a unary solution is higher than that from multi-component solutions. The initial flux values were the highest for membrane doped with $\underline{4}$. For a ternary mixture (solution V), the initial fluxes of metal ions transported across PIMs containing all carriers (1-4) decreased in the following order: $\mathrm{Zn}(\mathrm{II})>\mathrm{Cd}(\mathrm{II})>\mathrm{Ni}$ (II). Selectivity coefficients (S) Zn(II)/Cd(II) were approximately equal to 1.5 for PIMs with carriers 1-3 and equal to 2.8 for PIMs doped with 4 . Selectivity coefficients (S) $\mathrm{Cd}(\mathrm{II}) / \mathrm{Ni}(\mathrm{II})$ increased in order $\underline{\mathbf{1}}<\underline{\mathbf{2}}<\underline{\mathbf{3}}<\underline{\mathbf{4}}$ from 3.5 (1) up to 23.5 (4). Very high selectivity coefficients $\mathrm{Zn}$ (II)/Ni(II) were obtained when there was no cadmium in the mixture (solution IV), especially in the case of the carrier $\underline{4}$. Both the initial fluxes and selectivity coefficient values depended on the carrier used. This was caused by differences in both the basicity of the carriers and the stability constants of their complexes with metal ions. Octyl substituents at position 1 of the imidazole ring distinctly affected the hydrophobic properties of the molecule. An additional two methyl substituents at positions 
2 and 4 of the imidazole ring (due to the induction effect) were found to increase basicity by one order of magnitude, compared with that of 1-octylimidazole [45] (Figure 1). The strongest base was 1-octyl-2,4-dimethylimidazole (4) [45].

Table 2. Initial fluxes $\left(\mathrm{J}_{0}\right)$, selectivity order, and selectivity coefficients (S) for the competitive transport of $\mathrm{Zn}(\mathrm{II}), \mathrm{Cd}(\mathrm{II})$, and $\mathrm{Ni}(\mathrm{II})$ ions across PIMs doped with alkylimidazoles 1-4.

\begin{tabular}{|c|c|c|c|c|}
\hline Carrier & Solutions & Metal Ions & $\mathrm{J}_{0}\left(\mu \mathrm{mol} / \mathrm{m}^{2} \cdot \mathrm{s}\right)$ & $\begin{array}{c}\text { Selectivity Order } \\
\text { Selectivity Coefficients } \\
S_{\mathrm{Zn}(\mathrm{II}) / \mathrm{M}(\mathrm{II})}\end{array}$ \\
\hline \multirow{5}{*}{$\underline{\mathbf{1}}$} & I & $\mathrm{Zn}(\mathrm{II})$ & 16.32 & - \\
\hline & II & $\mathrm{Zn}(\mathrm{II})$ & 11.30 & $\mathrm{Zn}(\mathrm{II})>\mathrm{Cd}(\mathrm{II})$ \\
\hline & III & $\begin{array}{l}\mathrm{Cd}(\mathrm{II}) \\
\mathrm{Ni}(\mathrm{II})\end{array}$ & $\begin{array}{l}8.56 \\
2.42\end{array}$ & $\begin{array}{c}\mathrm{Cd}(\mathrm{II})>\mathrm{Ni}(\mathrm{II}) \\
3.5\end{array}$ \\
\hline & IV & $\begin{array}{l}\mathrm{Zn}(\mathrm{II} \\
\mathrm{Ni}(\mathrm{II})\end{array}$ & $\begin{array}{l}10.83 \\
1.07\end{array}$ & $\begin{array}{c}\mathrm{Zn}(\mathrm{II})>\mathrm{Ni}(\mathrm{II}) \\
10.1\end{array}$ \\
\hline & $\mathbf{V}$ & $\begin{array}{l}\mathrm{Zn}(\mathrm{II}) \\
\mathrm{Cd}(\mathrm{II}) \\
\mathrm{Ni}(\mathrm{II})\end{array}$ & $\begin{array}{c}10.76 \\
6.61 \\
1.18\end{array}$ & $\begin{array}{c}\mathrm{Zn}(\mathrm{II})>\mathrm{Cd}(\mathrm{II})>\mathrm{Ni}(\mathrm{II}) \\
\mathrm{S}_{\mathrm{Zn}(\mathrm{II}) / \mathrm{Cd}(\mathrm{II})}-1.6, \mathrm{~S}_{\mathrm{Zn}(\mathrm{II}) / \mathrm{Ni}(\mathrm{II})}-9.1\end{array}$ \\
\hline \multirow{5}{*}{$\underline{2}$} & I & $\mathrm{Zn}(\mathrm{II})$ & 12.45 & - \\
\hline & II & $\begin{array}{l}\mathrm{Zn}(\mathrm{II}) \\
\mathrm{Cd}(\mathrm{II})\end{array}$ & $\begin{array}{c}10.13 \\
6.24\end{array}$ & $\begin{array}{c}\mathrm{Zn}(\mathrm{II})>\mathrm{Cd}(\mathrm{II}) \\
1.6\end{array}$ \\
\hline & III & $\begin{array}{l}\mathrm{Cd}(\mathrm{II}) \\
\mathrm{Ni}(\mathrm{II})\end{array}$ & $\begin{array}{l}7.16 \\
0.45\end{array}$ & $\begin{array}{c}\mathrm{Cd}(\mathrm{II})>\mathrm{Ni}(\mathrm{II}) \\
15.9\end{array}$ \\
\hline & IV & $\begin{array}{l}\mathrm{Zn}(\mathrm{II}) \\
\mathrm{Ni}(\mathrm{II})\end{array}$ & $\begin{array}{l}9.82 \\
0.43\end{array}$ & $\begin{array}{c}\mathrm{Zn}(\mathrm{II})>\mathrm{Ni}(\mathrm{II}) \\
22.7\end{array}$ \\
\hline & $\mathbf{V}$ & $\begin{array}{l}\mathrm{Zn}(\mathrm{II}) \\
\mathrm{Cd}(\mathrm{II}) \\
\mathrm{Ni}(\mathrm{II})\end{array}$ & $\begin{array}{l}8.49 \\
5.83 \\
0.30 \\
\end{array}$ & 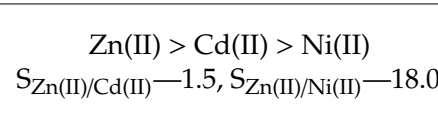 \\
\hline \multirow{5}{*}{$\underline{3}$} & $\mathbf{I}$ & $\mathrm{Zn}(\mathrm{II})$ & 11.68 & - \\
\hline & II & $\begin{array}{l}\mathrm{Zn}(\mathrm{II}) \\
\mathrm{Cd}(\mathrm{II})\end{array}$ & $\begin{array}{l}9.53 \\
7.01\end{array}$ & $\begin{array}{c}\mathrm{Zn}(\mathrm{II})>\mathrm{Cd}(\mathrm{II}) \\
1.4\end{array}$ \\
\hline & III & $\begin{array}{l}\mathrm{Cd}(\mathrm{II}) \\
\mathrm{Ni}(\mathrm{II})\end{array}$ & $\begin{array}{l}6.92 \\
0.35\end{array}$ & $\begin{array}{c}\mathrm{Cd}(\mathrm{II})>\mathrm{Ni}(\mathrm{II}) \\
19.8\end{array}$ \\
\hline & IV & $\begin{array}{l}\mathrm{Zn}(\mathrm{II}) \\
\mathrm{Ni}(\mathrm{II})\end{array}$ & $\begin{array}{c}10.02 \\
0.29\end{array}$ & $\begin{array}{c}\mathrm{Zn}(\mathrm{II})>\mathrm{Ni}(\mathrm{II}) \\
34.6\end{array}$ \\
\hline & V & $\begin{array}{l}\mathrm{Zn}(\mathrm{II}) \\
\mathrm{Cd}(\mathrm{II}) \\
\mathrm{Ni}(\mathrm{II})\end{array}$ & $\begin{array}{l}8.97 \\
5.61 \\
0.37\end{array}$ & 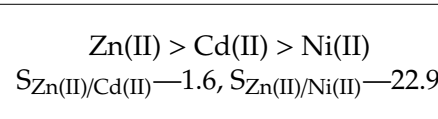 \\
\hline \multirow{5}{*}{$\underline{4}$} & I & $\mathrm{Zn}(\mathrm{II})$ & 28.13 & - \\
\hline & II & $\begin{array}{l}\mathrm{Zn}(\mathrm{II}) \\
\mathrm{Cd}(\mathrm{II})\end{array}$ & $\begin{array}{c}26.08 \\
9.24\end{array}$ & $\begin{array}{c}\mathrm{Zn}(\mathrm{II})>\mathrm{Cd}(\mathrm{II}) \\
2.8\end{array}$ \\
\hline & III & $\begin{array}{l}\mathrm{Cd}(\mathrm{II}) \\
\mathrm{Ni}(\mathrm{II})\end{array}$ & $\begin{array}{l}8.47 \\
0.36\end{array}$ & $\begin{array}{c}\mathrm{Cd}(\mathrm{II})>\mathrm{Ni}(\mathrm{II}) \\
23.5\end{array}$ \\
\hline & IV & $\begin{array}{l}\mathrm{Zn}(\mathrm{II}) \\
\mathrm{Ni}(\mathrm{II})\end{array}$ & $\begin{array}{c}27.12 \\
0.25\end{array}$ & $\begin{array}{c}\mathrm{Zn}(\mathrm{II})>\mathrm{Ni}(\mathrm{II}) \\
104.5\end{array}$ \\
\hline & $\mathbf{V}$ & $\begin{array}{l}\mathrm{Zn}(\mathrm{II}) \\
\mathrm{Cd}(\mathrm{II}) \\
\mathrm{Ni}(\mathrm{II})\end{array}$ & $\begin{array}{l}25.44 \\
7.62 \\
0.29\end{array}$ & $\begin{array}{c}\mathrm{Zn}(\mathrm{II})>\mathrm{Cd}(\mathrm{II})>\mathrm{Ni}(\mathrm{II}) \\
\mathrm{S}_{\mathrm{Zn}(\mathrm{II}) / \mathrm{Cd}(\mathrm{II})}-3.3, \mathrm{~S}_{\mathrm{Zn}(\mathrm{II}) / \mathrm{Ni}(\mathrm{II})}-87.7\end{array}$ \\
\hline
\end{tabular}

These form electrically neutral ion pairs with anions that penetrate the membrane in the co-transport:

$$
\mathrm{M}^{2+}+\mathrm{L}+2 \mathrm{~A}-\leftrightarrow(\mathrm{ML}) \mathrm{A}_{2}
$$

where $\mathrm{M}^{2+}$ is the metal ion, $\mathrm{L}$ is the carrier, and $\mathrm{A}-$ is the co-transported anion. 
The stability constants values of $\mathrm{Zn}(\mathrm{II}), \mathrm{Cd}(\mathrm{II})$, and $\mathrm{Ni}(\mathrm{II})$ complexes with the investigated carriers are summarized in Table 3.

Table 3. Comparison of the stability constants $\beta_{n}$ of $\mathrm{Zn}(\mathrm{II}), \mathrm{Cd}(\mathrm{II})$, and $\mathrm{Ni}(\mathrm{II})$ complexes with alkylimidazole $\mathbf{1 - 4}$, at $25^{\circ} \mathrm{C}$, ionic strength $0.5 \mathrm{M}\left(\mathrm{KNO}_{3}\right)$.

\begin{tabular}{|c|c|c|c|c|c|c|}
\hline Ligand/Carrier & Metal Ion & $\log \beta_{1}$ & $\log \beta_{2}$ & $\log \beta_{3}$ & $\log \beta_{4}$ & Ref. \\
\hline \multirow{3}{*}{$\underline{1}$} & $\mathrm{Zn}(\mathrm{II})$ & 2.73 & 4.15 & 6.64 & 10.18 & [55] \\
\hline & $\mathrm{Cd}(\mathrm{II})$ & 1.95 & 2.81 & 4.00 & 5.20 & [56] \\
\hline & $\mathrm{Ni}(\mathrm{II})$ & 0.79 & 3.90 & 6.20 & 8.10 & [57] \\
\hline \multirow{3}{*}{$\underline{2}$} & $\mathrm{Zn}(\mathrm{II})$ & 1.96 & 4.45 & 6.80 & 9.10 & [58] \\
\hline & $\mathrm{Cd}(\mathrm{II})$ & 1.03 & 2.20 & 3.45 & 5.05 & [58] \\
\hline & $\mathrm{Ni}(\mathrm{II})$ & 0.11 & 0.47 & 1.19 & 2.63 & [59] \\
\hline \multirow{3}{*}{$\underline{3}$} & $\mathrm{Zn}(\mathrm{II})$ & 2.04 & 3.50 & 6.20 & 6.90 & [60] \\
\hline & $\mathrm{Cd}(\mathrm{II})$ & 1.26 & 2.20 & 3.93 & 5.11 & [61] \\
\hline & $\mathrm{Ni}(\mathrm{II})$ & 0.69 & 1.04 & 2.00 & 2.92 & [61] \\
\hline \multirow{3}{*}{$\underline{4}$} & $\mathrm{Zn}(\mathrm{II})$ & 1.65 & 2.17 & 4.48 & 6.39 & [62] \\
\hline & $\mathrm{Cd}(\mathrm{II})$ & 1.17 & 2.53 & 4.21 & 5.68 & [62] \\
\hline & $\mathrm{Ni}(\mathrm{II})$ & 0.09 & 0.22 & 1.11 & 2.05 & [62] \\
\hline
\end{tabular}

As we can see from Table 2, using 1-octyl-2,4-dimethylimidazole (4) allowed us to obtain the highest value of initial flux transport of zinc(II) ions $\left(28 \mu \mathrm{mol} / \mathrm{m}^{2} \cdot \mathrm{s}\right)$ from the solution and the highest coefficient of separation in relation to $\mathrm{Ni}(\mathrm{II})$ and $\mathrm{Cd}(\mathrm{II})$ ions. Zinc(II) ions are selectively separated from chloride water solutions in the presence of $\mathrm{Cd}(\mathrm{II}), \mathrm{Co}(\mathrm{II}), \mathrm{Cu}(\mathrm{II})$, and $\mathrm{Ni}(\mathrm{II})$ ions in the process of transport through a PIM containing D2EHPA. The best Zn(II) separation selectivity compared to the other ions was obtained at $\mathrm{pH} \leq 2.0$. The ion transport rate decreased in the following order: $\mathrm{Zn}(\mathrm{II})>\mathrm{Cu}(\mathrm{II})>\mathrm{Co}(\mathrm{II})>\mathrm{Ni}(\mathrm{II})>\mathrm{Cd}(\mathrm{II})$. The $\mathrm{Zn}(\mathrm{II}) / \mathrm{Cd}(\mathrm{II}), \mathrm{Zn}(\mathrm{II}) / \mathrm{Ni}(\mathrm{II}), \mathrm{Zn}(\mathrm{II}) / \mathrm{Co}(\mathrm{II})$, and Zn(II)/Cu(II) selectivity ratios equaled 879, 24.4, 9.90, and 6.50, respectively [63,64], whereas using Cyanex 301 and Cyanex 302 enabled the separation of $\mathrm{Pb}$ (II) ions from $\mathrm{Zn}$ (II) and $\mathrm{Cd}(\mathrm{II})$ ions. The $\mathrm{Pb} / \mathrm{Cd}$ and $\mathrm{Pb} / \mathrm{Zn}$ separation factors for Cyanex 301 were 1.7 and 2.8, and for Cyanex 302, 1.9 and 4.4, respectively [65].

The use of alkylimidazoles $\underline{\mathbf{1}} \mathbf{-} \underline{\mathbf{4}}$ gave a better effect of the separation of $\mathrm{Zn}(\mathrm{II})$ and $\mathrm{Ni}$ (II) ions than using the polymer inclusion membrane with $\beta$-cyclodextrin [66], PNP-16-crown-6-derivatives [67], and tri-n-octylamine [68].

Separation of zinc(II) from cobalt(II) ions was possible using supported liquid membrane with DP-8R (di(2-ethylhexyl) phosphoric acid) as a carrier. Using $0.5 \mathrm{M}$ sulphuric acid as receiving phase, with the increase of the initial DP-8R concentration (5-30\%), the value of permeability of $\mathrm{Zn}$ (II) increased from 2.8 to $4.5 \cdot 10^{-3} \mathrm{~cm} / \mathrm{s}$ [69].

Additionally, the transport of $\mathrm{Zn}(\mathrm{II})$ ions across the supported liquid membrane with TDDA (tri-n-dodecylamine) was possible. The maximum initial flux of $\mathrm{Zn}$ (II) (almost $10 \cdot 10^{-11} \mathrm{~mol} / \mathrm{m}^{2} \cdot \mathrm{s}$ ) was achieved at $0.80 \mathrm{~mol} / \mathrm{dm}^{3}$ of TDDA in the membrane phase and $2.0 \mathrm{~mol} / \mathrm{dm}^{3}$ of $\mathrm{HCl}$ and $\mathrm{NaOH}$ in feed and receiving solution, respectively [70]. Therefore, the initial flux of $\mathrm{Zn}$ (II) ion transport across the liquid membrane with TDDA was lower than using the investigated alkylimidazoles $\mathbf{1}-\underline{\mathbf{4}}$.

Ion carriers embedded in the membrane interacted with metal ions in the diffusion-controlled water phase to form complexes.

As seen in Table 3, the stability constants for 1-octylimidazole (1) complexes with all metal ions were the highest. The presence of the methyl substituent at positions 2 or 4 of the imidazole ring hindered the formation of each metal complex (steric effect). The stability constants of $\mathrm{Zn}$ (II), Cd(II), and $\mathrm{Ni}$ (II) complexes increased in the following order: $\mathrm{Zn}(\mathrm{II})>\mathrm{Cd}$ (II) $>\mathrm{Ni}$ (II) (Table 3). The steric effect differentiated the complexing properties of the metal ions tested, so it was possible to separate them. 
In aqueous solutions, cations of $\mathrm{Zn}(\mathrm{II}), \mathrm{Cd}(\mathrm{II})$, and $\mathrm{Ni}$ (II) existed in the form of octahedral aqua complexes $\left(\mathrm{M}_{2}\left(\mathrm{H}_{2} \mathrm{O}\right)_{6}\right)^{2+}$. In the case of $\mathrm{Zn}(\mathrm{II})$ and $\mathrm{Cd}(\mathrm{II})$ ions, owing to the effect of ligands (extractants), octahedral aqua complexes of certain cations tended to change their coordination number (c.n.) from 6 to 4 , and they changed their coordination sphere into square flat or deformed tetrahedron, depending on the structure of their d-electron layer. The process is illustrated by Equation (9).

$$
\begin{gathered}
\left(\mathrm{M}\left(\mathrm{H}_{2} \mathrm{O}\right)_{6-n} \mathrm{~L}_{n}\right)^{2+} \leftrightarrow\left(\mathrm{M}\left(\mathrm{H}_{2} \mathrm{O}\right)_{4-n} \mathrm{~L}_{n}\right)^{2+}+2 \mathrm{H}_{2} \mathrm{O} \\
\left(\mathrm{M}\left(\mathrm{H}_{2} \mathrm{O}\right)_{6-\mathrm{n}+1} \mathrm{~L}_{\mathrm{n}-1}\right)^{2+}+\mathrm{L} \leftrightarrow\left(\mathrm{M}\left(\mathrm{H}_{2} \mathrm{O}\right)_{4-n} \mathrm{~L}_{n}\right)^{2+}+3 \mathrm{H}_{2} \mathrm{O}
\end{gathered}
$$

The steric effect of the substituent at position 2 or 4 decreases the stability constants of octahedral complexes of all the metals studied, although it does not hinder the formation of tetrahedral species $[29,30,53,55,58-62]$. The formation of tetrahedral complexes with 1-alkylimidazoles has been proven for the $\mathrm{Zn}(\mathrm{II})$ and $\mathrm{Cd}(\mathrm{II})$ ions $[42,56,59,71]$. The $\mathrm{Zn}(\mathrm{II})$ ions were transported across PIMs most effectively.

The $\mathrm{Ni}$ (II) ions most of all formed 6-coordination complexes because they have a rigid octahedral structure that is hard to deform. This may be the reason for their small transport.

It seems (compare Tables 2 and 3) that the initial flux values corresponded to those of the stability constants of the complexes.

\subsection{Recovery of Metal}

The recovery factor (RF) of $\mathrm{Zn}(\mathrm{II})$ transport across PIM doped alkylimidazoles (1-4) from equimolar nitrate solutions of $\mathrm{Zn}(\mathrm{II}), \mathrm{Cd}(\mathrm{II})$, and $\mathrm{Ni}(\mathrm{II})$ into $0.5 \mathrm{M} \mathrm{H}_{2} \mathrm{SO}_{4}$ is presented in Figure 4 . The $\mathrm{RF}$ values depended on the carrier in PIMs used.

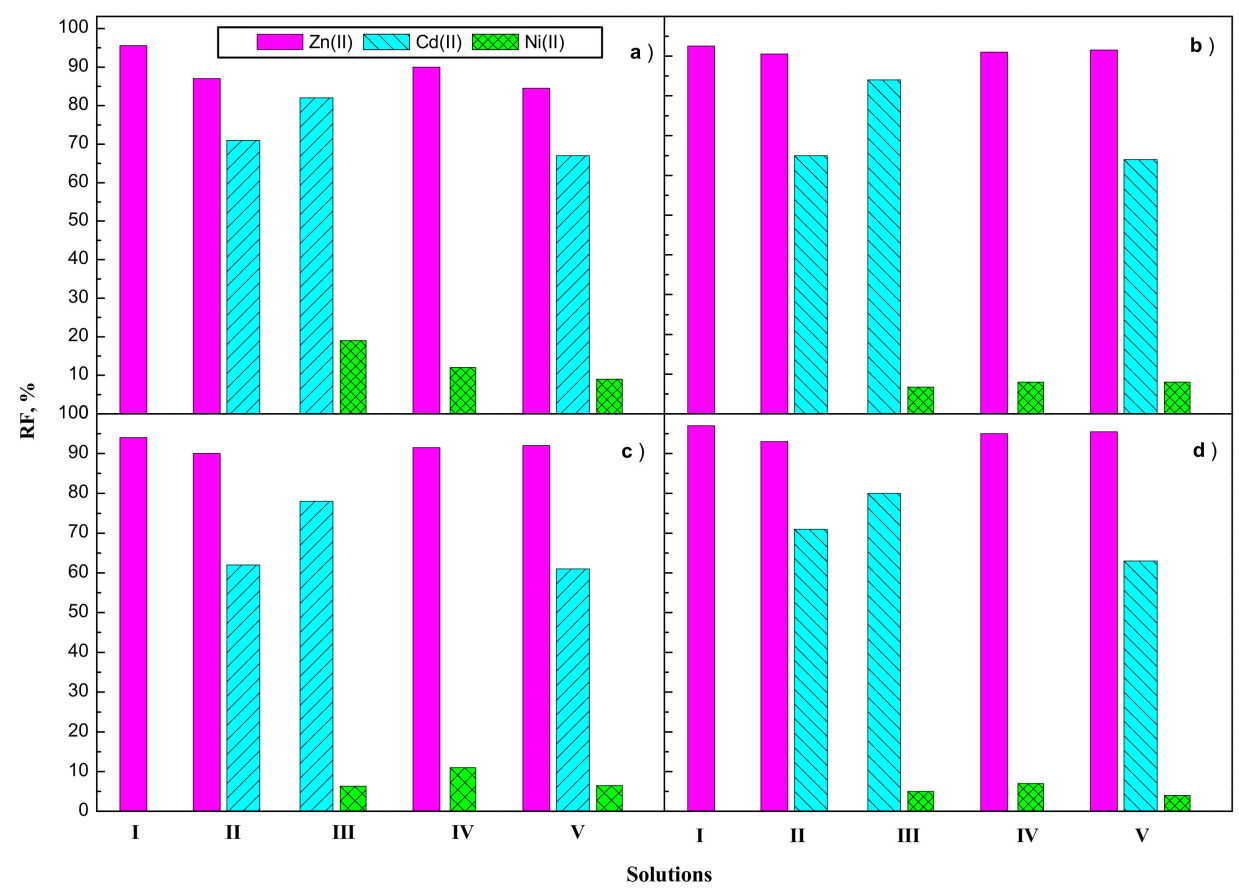

Figure 4. Recovery factors (RF) of $\mathrm{Zn}(\mathrm{II}), \mathrm{Cd}(\mathrm{II})$, and Ni(II) competitive transport across PIM doped alkylimidazoles 1 (a), 2 (b), 3 (c), and 4 (d).

The highest recovery factors (RF) were found for $\mathrm{Zn}(\mathrm{II})$ ions for unary solution for PIM doped $\underline{4}$ (97\%). The RF values of $\mathrm{Zn}(\mathrm{II})$ ions from binary $\mathrm{Zn}(\mathrm{II})-\mathrm{Cd}(\mathrm{II})$ solutions (solution II) increased in the following order: $\underline{\mathbf{1}}<\mathbf{2}=\underline{\mathbf{3}}<\underline{\mathbf{4}}$. For the $\mathrm{Zn}(\mathrm{II})-\mathrm{Ni}(\mathrm{II})$ mixture (solution IV) the RF values were almost the same (c.a. $90-\overline{9} 1 \%$ ) in the case of $\underline{\mathbf{1}}-\underline{\mathbf{3}}$ carriers, but for carrier $\underline{\mathbf{4}}$, RF for the $\mathrm{Zn}$-Ni mixture increased 
to $95 \%$. For carrier 4 , in the case of a ternary $\mathrm{Zn}(\mathrm{II})-\mathrm{Cd}(\mathrm{II})-\mathrm{Ni}(\mathrm{II})$-mixture, the $\mathrm{RF}$ for $\mathrm{Zn}(\mathrm{II}), \mathrm{Cd}(\mathrm{II})$, and $\mathrm{Ni}(\mathrm{II})$ were $95.5,63$, and 4 percent, respectively.

The lowest RF values were obtained for $\mathrm{Ni}(\mathrm{II})$ ions, which were the slowest transported by this type of membrane. Practically, Ni(II) ions remained in the feeding phase.

\subsection{Membrane Diffusion Coefficients of Zn(II), Cd(II), and Ni(II) Complexes with Alkylimidazole (1- $\underline{\mathbf{4}})$}

In Figure $5 \mathrm{~A}-\mathrm{D}$, the correlation graphs $\left(\mathrm{M}^{2+}\right)_{0-}\left(\mathrm{M}^{2+}\right)_{\mathrm{t}}$ versus time of metal ions transport across

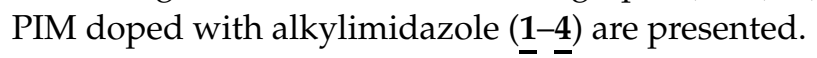

A

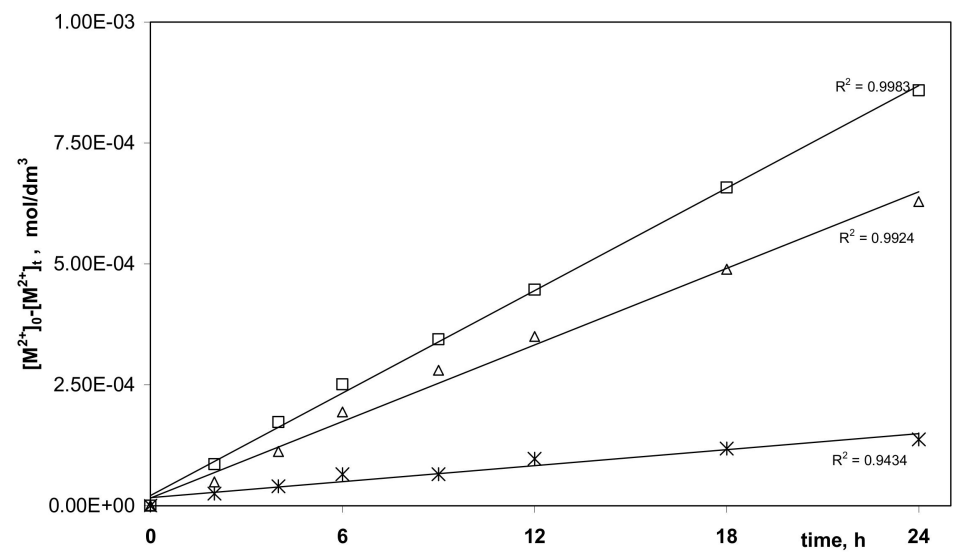

B

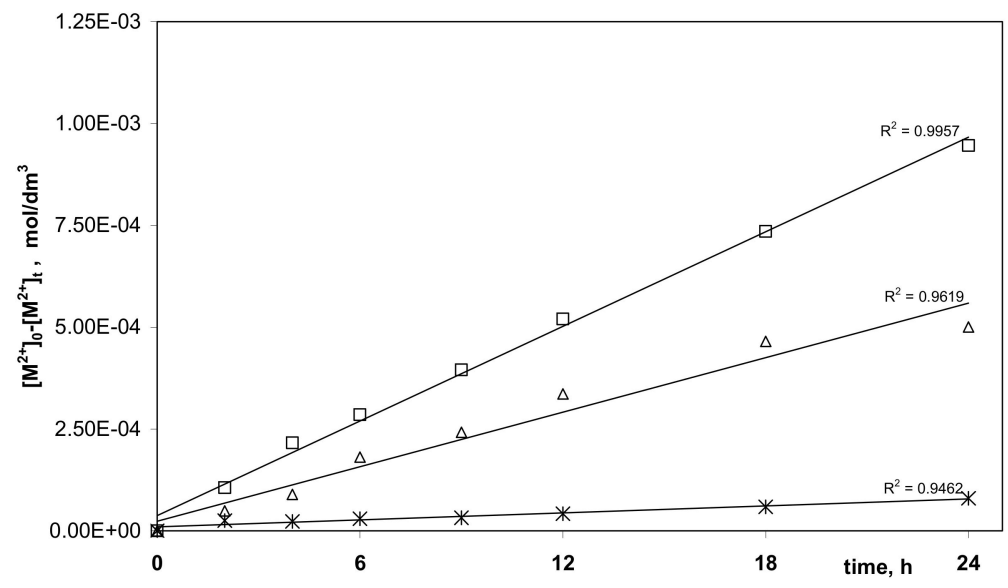

Figure 5. Cont. 


\section{C}

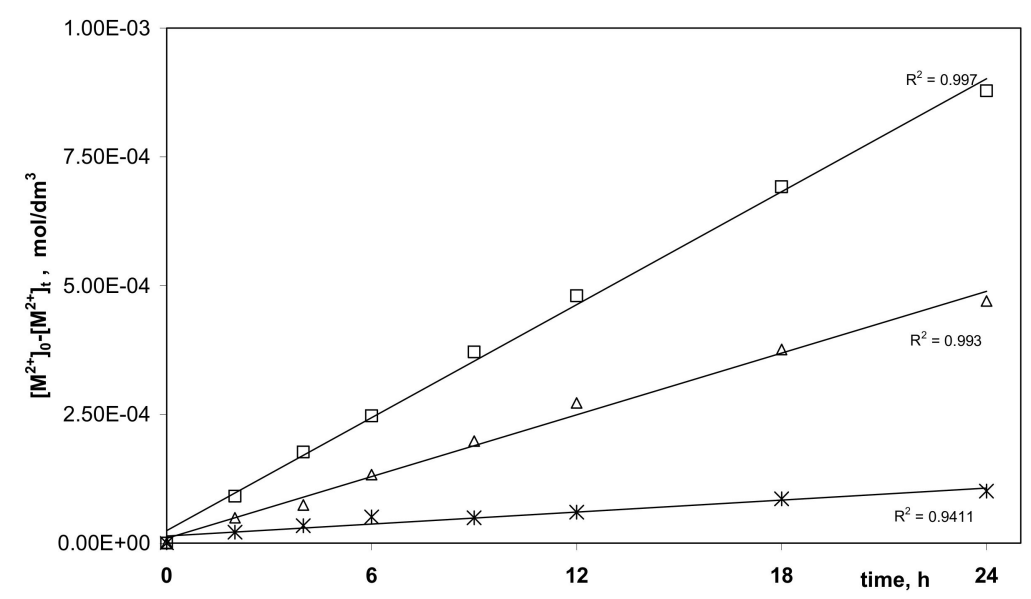

D

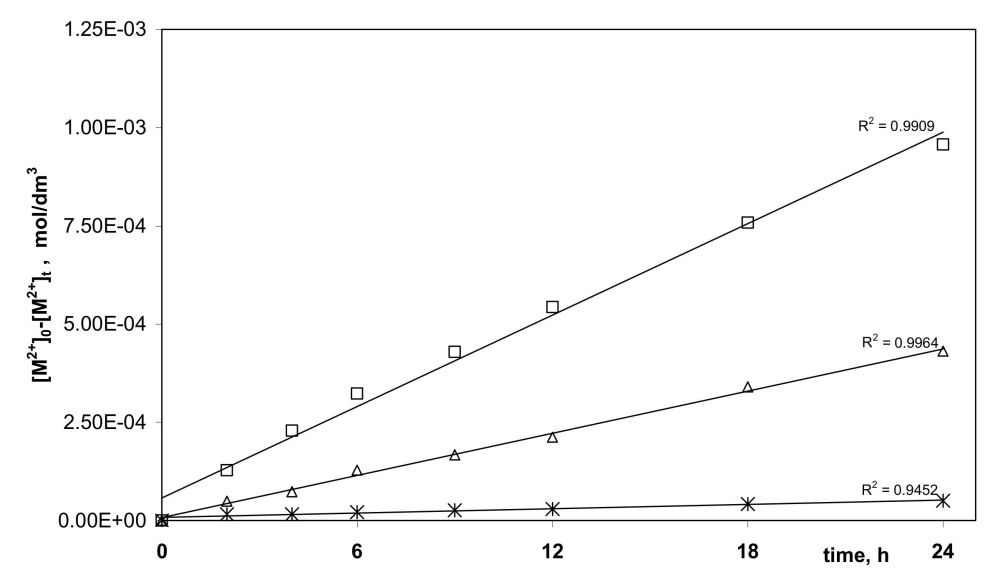

Figure 5. Relation of $\left[\mathrm{M}^{2+}\right]_{0-}\left[\mathrm{M}^{2+}\right]_{t}$ plotted vs. time for $\mathrm{Zn}(\mathrm{II})(\square), \mathrm{Cd}(\mathrm{II})(\Delta)$, and Ni(II) $\left(^{*}\right)$, transport across PIMs doped with 1-octylimdazole (A), 1-octyl-2-methylimidazole (B), 1-octyl-4-methylimidazole (C) and 1-octyl-2,4-methylimidazole (D), respectively.

The diffusion coefficient of $\mathrm{M}(\mathrm{II})\left(\mathrm{D}_{\mathrm{o}}\right)$ was calculated from the equation:

$$
\mathrm{D}_{\mathrm{o}}=\mathrm{d}_{\mathrm{o}} / \Delta_{\mathrm{o}}
$$

where $d_{o}$ is the thickness of the membrane $(0.003 \mathrm{~cm})$ and $\Delta_{o}$ could be evaluated by plotting $\left(\mathrm{M}^{2+}\right)_{0-}\left(\mathrm{M}^{2+}\right)_{\mathrm{t}}$ vs time.

The corrected (normalized) membrane diffusion coefficient $D_{o, n}$ [50], which considers the morphological features inside the membrane $(\varepsilon$-porosity and $\tau$-tortuosity), was calculated from the following equation:

$$
\mathrm{D}_{\mathrm{o}, \mathrm{n}}=\mathrm{D}_{\mathrm{o}} \cdot(\varepsilon / \tau)
$$

The obtained values of diffusion coefficients are presented in Table 4. 
Table 4. Diffusion coefficients normalized for competitive transport of $\mathrm{Zn}(\mathrm{II}), \mathrm{Cd}(\mathrm{II})$, and $\mathrm{Ni}(\mathrm{II})$ ions through PIMs doped with alkylimidazole (1-4).

\begin{tabular}{ccccc}
\hline Carrier & Metal Ion & $\boldsymbol{\Delta}_{\mathbf{o}}(\mathbf{s} / \mathbf{m})$ & $\mathbf{D}_{\mathbf{o}}\left(\mathbf{c m}^{2} / \mathbf{s}\right)$ & $\mathbf{D}_{\mathbf{o}, \mathbf{n}}\left(\mathbf{c m}^{2} / \mathbf{s}\right)$ \\
\hline \multirow{2}{*}{} & $\mathrm{Zn}(\mathrm{II})$ & 107.25 & $2.04 \cdot 10^{-8}$ & $2.11 \cdot 10^{-9}$ \\
& $\mathrm{Cd}(\mathrm{II})$ & 108.49 & $7.16 \cdot 10^{-9}$ & $7.40 \cdot 10^{-10}$ \\
$\underline{\mathbf{2}}$ & $\mathrm{Ni}(\mathrm{II})$ & 1010.11 & $4.39 \cdot 10^{-11}$ & $4.53 \cdot 10^{-12}$ \\
\hline \multirow{2}{*}{$\mathbf{3}$} & $\mathrm{Zn}(\mathrm{II})$ & 106.14 & $1.92 \cdot 10^{-8}$ & $2.01 \cdot 10^{-9}$ \\
& $\mathrm{Cd}(\mathrm{II})$ & 107.63 & $6.76 \cdot 10^{-9}$ & $7.14 \cdot 10^{-10}$ \\
& $\mathrm{Ni}(\mathrm{II})$ & 1010.65 & $4.15 \cdot 10^{-11}$ & $4.27 \cdot 10^{-12}$ \\
\hline \multirow{2}{*}{$\underline{\mathbf{4}}$} & $\mathrm{Zn}(\mathrm{II})$ & 106.67 & $1.72 \cdot 10^{-8}$ & $1.98 \cdot 10^{-9}$ \\
& $\mathrm{Cd}(\mathrm{II})$ & 108.02 & $6.34 \cdot 10^{-9}$ & $6.75 \cdot 10^{-10}$ \\
& $\mathrm{Ni}(\mathrm{II})$ & 1010.50 & $4.59 \cdot 10^{-11}$ & $4.83 \cdot 10^{-12}$ \\
\hline & $\mathrm{Zn}(\mathrm{II})$ & 106.08 & $1.53 \cdot 10^{-8}$ & $1.74 \cdot 10^{-9}$ \\
& $\mathrm{Cd}(\mathrm{II})$ & 107.15 & $6.06 \cdot 10^{-9}$ & $6.58 \cdot 10^{-10}$ \\
& $\mathrm{Ni}(\mathrm{II})$ & 1010.61 & $4.72 \cdot 10^{-11}$ & $4.91 \cdot 10^{-12}$ \\
\hline
\end{tabular}

Values of diffusion coefficients determined in this study are comparable with those presented in the literature data for different membranes, which are in the range of $10^{-12}$ to $10^{-6} \mathrm{~cm}^{2} / \mathrm{s}$, and show that the limiting step of the process is the transfer of metal complexes across the membrane barrier. The value of the diffusion coefficient of M(II)-carrier species of $4.15 \cdot 10^{-11}-2.04 \cdot 10^{-8} \mathrm{~cm}^{2} / \mathrm{s}$ is smaller than the value of $1.5 \cdot 10^{-7} \mathrm{~cm}^{2} / \mathrm{s}$ reported for the $\mathrm{Pb}$ (II) complex with the di-(2-ethylhexyl) phosphoric acid (D2EHPA) in PIMs reported by Salazar-Alvarez et al. [50].

The values of normalized diffusion coefficients (considering membrane porosity and tortuosity) of M(II)-carrier complexes, obtained in the process of transport across PIMs containing alkylimidazole (1-4) from the equimolar $\mathrm{Zn}(\mathrm{II})-\mathrm{Cd}(\mathrm{II})-\mathrm{Ni}(\mathrm{II})$ solution, are in the range $4.53 \cdot 10^{-12}-2.11 \cdot 10^{-9} \mathrm{~cm}^{2} / \mathrm{s}$.

Thus, the rate of transport of non-ferrous metal ions across PIMs doped with alkylimidazole (1- $-\underline{4})$ is determined by the diffusion rate of the $\mathrm{M}(\mathrm{II})$-carrier complexes across the membrane.

\section{Conclusions}

Zinc(II) ions can be effectively separated from equimolar aqueous solutions of zinc, cadmium, and nickel nitrates by using the transport across polymer inclusion membranes doped with 1-octylimidazole (1), 1-octyl-2-methylimidazole (2), 1-octyl-4-methylimidazole (3) , and 1-octyl-2,4-dimethylimidazole (ㅁ) . The initial fluxes of metal ion transport decreased in the following order: $\mathrm{Zn}(\mathrm{II})>\mathrm{Cd}$ (II) $>\mathrm{Ni}$ (II). The transport rate of the metal ions across PIMs was determined by the diffusion rate of the $\mathrm{M}(\mathrm{II})$-carrier complexes across the membrane.

The best result achieved for $\mathrm{Zn}$ (II) removal after $24 \mathrm{~h}$ was $95.5 \%$ for the ternary $\mathrm{Zn}$ (II)-Cd(II)-Ni(II) solution for PIM doped 1-octyl-2,4-dimethylimidazole (4). For this membrane, the separation coefficients for $\mathrm{Zn}(\mathrm{II}) / \mathrm{Cd}(\mathrm{II}), \mathrm{Zn}(\mathrm{II}) / \mathrm{Ni}(\mathrm{II})$, and $\mathrm{Cd}(\mathrm{II}) / \mathrm{Ni}(\mathrm{II})$ were $2.8,104.5$, and 23.5, respectively. This effective separation was possibly achieved due to the steric effect induced by the presence of the methyl substituent in a direct vicinity of the donor nitrogen atom in the carrier molecule. It differentiates the process of the complex formation, particularly for $\mathrm{Zn}$ (II) and $\mathrm{Ni}$ (II). Carriers whose particles have a steric effect can also be used to separate $\mathrm{Co}(\mathrm{II})$ ions, because this cation has the ability to change the coordination sphere from octahedron to tetrahedron.

Author Contributions: E.R.-L. contributed the concept of the article. M.U. prepared the membranes and performed and analyzed the transport studies. E.R.-L. analyzed the data of SEM and AFM images of membranes. M.U. wrote introduction. E.R.-L. discussed the results and conclusions.

Funding: The financial support of the Ministry of Science and Higher Education, Republic of Poland (BS 13/2013), is gratefully acknowledged. 
Acknowledgments: The research (SEM, AFM) was carried out with the equipment-specialized analytical laboratories of the Poznan Science and Technology Park of the Adam Mickiewicz University Foundation in Poznan and Faculty of Chemistry of Nicolaus Copernicus University in Torun.

Conflicts of Interest: The authors declare no conflict of interest.

\section{References}

1. Cote, G. Hydrometallurgy of strategic metals. Solvent Extr. Ion Exch. 2000, 18, 703-727. [CrossRef]

2. Habashi, F. Textbook of Hydrometallurgy, 2nd ed.; Metallurgie Extractive Quebec: Quebec, QC, Canada, 2007.

3. Rao, S.R. Resource, Recovery and Recycling from Metallurgical Wastes; Elsevier: Amsterdam, The Netherlands, 2006.

4. Pretz, T.; Julius, J. Metal Waste; Waste-A Handbook for Management; Academic Press: Cambridge, MA, USA, 2011; Chapter 6; pp. 89-99.

5. Wang, L.K.; Shammas, N.K.; Hung, Y.-T. Waste Treatment in the Metal Manufacturing, Forming, Coating and Finishing Industries; CRC Press Taylor and Francis group: Boca Raton, FL, USA, 2009.

6. Rydberg, J.; Cox, M.; Musakis, C.; Choppin, G.R. Principles and Practices of Solvent Extraction. Revised and Expanded, 2nd ed.; M. Dekker, Inc.: New York, NY, USA, 2004; ISBN 9780824750633.

7. Kislik, V.S. Solvent Extraction-Classical and Novel Approaches; Elsevier B.V.: Amsterdam, The Netherlands, 2012; ISBN 978-0-444-53778-2. [CrossRef]

8. Mapatac, L.C. Handbook of Separation Process Technology; Delve Publishing LLC: Oakville, Canada, 2017; ISBN 9781680957303.

9. Schlesinger, M.E.; King, M.J.; Sole, K.C.; Davenport, W.G. Solvent Extraction, Extractive Metallurgy of Copper, 5th ed.; Elsevier B.V.: Amsterdam, The Netherlands, 2011; pp. 323-347. ISBN 9780080967899.

10. Jha, M.K.; Kumar, V.; Singh, R.J. Solvent extraction of zinc from chloride solutions. Solvent Extr. Ion Exch. 2002, 20, 389-405. [CrossRef]

11. Jha, M.K.; Kumar, V.; Jeong, J.; Lee, J. Review on solvent extraction of cadmium from various solutions. Hydrometallurgy 2012, 111, 1-9. [CrossRef]

12. Schimmel, K.A.; Ilias, S.; Akella, S. Nondispersive liquid-liquid extraction of $\mathrm{Zn}(\mathrm{II}), \mathrm{Cu}(\mathrm{II}), \mathrm{Co}(\mathrm{II})$, and Cd(II) from dilute solution with DEHPA in a hollow-fiber membrane module. Sep. Sci. Technol. 2001, 36, 805-821. [CrossRef]

13. Wassink, B.; Dreisinger, D.; Howard, J. Solvent extraction separation of zinc and cadmium from nickel and cobalt using Aliquat 336, a strong base anion exchanger, in the chloride and thiocyanate forms. Hydrometallurgy 2000, 57, 235-252. [CrossRef]

14. Wejman-Gibas, K.; Pilsniak-Rabiega, M.; Ochromowicz, K. Solvent extraction of zinc(II) from ammonia leaching solution by LIX 54-100, LIX 84I and TOA. Physicochem. Probl. Miner. Process. 2017, 53, $202-211$.

15. Szymanowski, J. Kinetics and interfacial phenomena. Solvent Extr. Ion Exch. 2000, 18, 728-751. [CrossRef]

16. Fleitlikh, I.U.; Grigorieva, M.A.; Logutenko, O.A. Extraction of non-ferrous metals and iron with systems based on bis(2,4,4-trimethylpentyl) dithiophosphinic acid (CYANEX 301). A review. Solvent Extr. Ion Exch. 2018, 36, 1-21. [CrossRef]

17. Aguilar, M.; Cortina, J.L. Solvent Extraction and Liquid Membranes: Fundamentals and Applications in New Materials; CRC Pres Taylor and Francis group LLC: Baca Raton, FL, USA, 2010; ISBN 9780824740153.

18. Kislik, V. Liquid Membranes-Principles and Applications in Chemical Separations and Wastewater Treatment; Elsevier: Burlington, NY, USA, 2010; ISBN 9780444532183.

19. Ulbricht, M. Advanced functional polymer membranes. Polymer 2006, 47, 2217-2262. [CrossRef]

20. Sgarlata, C.; Arena, G.; Longo, E.; Zhang, D.; Yang, Y.; Bartsch, R.A. Heavy metal separation with polymer inclusion membranes. J. Membrane Sci. 2008, 323, 444-451. [CrossRef]

21. Hosseini, S.S.; Bringas, E.; Tan, N.R.; Ortiz, I.; Ghahramani, M.; Shahmirzadi, M.A.A. Recent progress in development of high performance polymeric membranes and materials for metal plating wastewater treatment: A review. J. Water Proc. Eng. 2016, 9, 78-110. [CrossRef]

22. Radzyminska-Lenarcik, E.; Ulewicz, R.; Ulewicz, M. Zinc recovery from model and waste solutions using polymer inclusion membrane (PIMs) with 1-octyl-4-methylimidazole. Desalin. Water Treat. 2018, 102, 211-219. [CrossRef] 
23. Radzyminska-Lenarcik, E.; Ulewicz, M. Selective transport of $\mathrm{Cu}(\mathrm{II})$ across a polymer inclusion membrane with 1-alkylimidazole from nitrate solutions. Sep. Sci. Technol. 2012, 47, 1113-1118. [CrossRef]

24. Bryan, Y.O.; Truong, Y.B.; Cattrall, R.W.; Kyratzis, I.L.; Kolev, S.D. A new generation of highly stable and permeable polymer inclusion membranes (PIMs) with their carrier immobilized in a crosslinked semi-interpenetrating polymer network. Application to the transport of thiocyanate. J. Membr. Sci. 2017, 529, 55-62. [CrossRef]

25. Senhadji-Kebiche, O.; Belaid, T.; Benamor, M. Polymer inclusion membrane (PIM) as competitive material for applications in SPE for water treatment process. Open Access Libr. J. 2014, 1, e758. [CrossRef]

26. Ulewicz, M.; Radzyminska-Lenarcik, E. Application of polymer and supported membranes with 1-decyl-4-methylimidazole for pertraction of transition metal ions. Sep. Sci. Technol. 2014, 49, 1713-1721. [CrossRef]

27. Altin, S.; Alemdar, S.; Atlin, A.; Yildririm, Y. Facilitated transport of Cd(II) through a supported liquid membrane with Aliquat 336 as a carrier. Sep. Sci. Technol. 2011, 46, 754-764. [CrossRef]

28. Aguilar, J.C.; Sanches-Castellanos, M.; de San Miguel, E.R.; de Gyves, J. Cd(II) and Pb(II) extraction and transport modeling in SLM and PIM systems using Kelex 100 as carrier. J. Membr. Sci. 2001, 190, 107-114. [CrossRef]

29. Ulewicz, M.; Radzymińska-Lenarcik, E. Application of polymer inclusion membranes doped with 1-hexyl-4-methylimidazole for pertraction of zinc(II) and other transition metal ions. Physicochem. Probl. Miner. Process. 2015, 51, 447-460.

30. Ulewicz, M.; Radzyminska-Lenarcik, E. Application of supported and polymer membrane with 1-decyl-2-methylimidazole for separation of transition metal ions. Physicochem. Probl. Miner. Process. 2012, 48, 91-102.

31. Ncib, S.; Barhoumi, A.; Bouguerra, W.; Larchet, C.; Dammak, L.; Hamrouni, B.; Elaloui, E. Preparation and characterization of cellulose triacetate polymer inclusion membrane blended with acetylated kraft lignin: Effect of AKL and application to the copper(II) extraction from acidic media. Desalin. Water Treat. 2018, 104, 263-272. [CrossRef]

32. Annane, K.; Sahmoune, A.; Montels, P.; Tingry, S. Polymer inclusion membrane extraction of cadmium(II) with Aliquat 336 in micro-channel cell. Chem. Eng. Res. Des. 2015, 94, 605-610. [CrossRef]

33. Baczynska, M.; Regel-Rosocka, M.; Nowicki, M.; Wiśniewski, M. Effect of the structure of polymer inclusion membranes on $\mathrm{Zn}(\mathrm{II})$ transport from chloride aqueous solutions. J. Appl. Polym. Sci. 2015, 132, 42319-42329. [CrossRef]

34. Inês, M.; Almeida, G.S.; Cattrall, R.W.; Kolev, S.D. Recent trends in extraction and transport of metal ions using polymer inclusion membranes (PIMs). J. Membr. Sci. 2012, 415, 9-23.

35. Kozlowski, C.A.; Walkowiak, W. Applicability of liquid membranes in chromium(VI) transport with amines as ion carriers. J. Membr. Sci. 2005, 266, 143-150. [CrossRef]

36. Gherrou, A.; Kerdjoudj, H.; Molinari, R.; Seta, P.; Drioli, E. Fixed sites plasticized cellulose triacetate membranes containing crown ethers for silver(I), copper(II) and gold(III) ions transport. J. Membr. Sci. 2004, 228, 149-157. [CrossRef]

37. Gherrou, A.; Kerdjoudj, H. Specific membrane transport of silver and copper as $\mathrm{Ag}(\mathrm{CN})_{3}{ }^{2-}$ and $\mathrm{Cu}(\mathrm{CN})_{4}{ }^{3-}$ ions through a supported liquid membrane using $\mathrm{K}^{+}$-crown ether as a carrier. Desalination 2003, 151, 87-94. [CrossRef]

38. Arous, O.; Amara, M.; Kerdjoudj, H. Synthesis and characterization of cellulose triacetate and poly(ethylene imine) membranes containing a polyether macrobicyclic: Their application to the separation of copper(II) and silver(I) ions. J. Appl. Polym. Sci. 2004, 93, 1401-1410. [CrossRef]

39. Xu, J.; Wang, L.; Shen, W.; Paimin, R.; Wang, X. The Influence of the Interior Structure of Aliquat 336/PVC membranes to their extraction behavior. Sep. Sci. Technol. 2005, 39, 3527-3539. [CrossRef]

40. Gherrou, A.; Kerdjoudj, H.; Molinari, R.; Seta, P. Preparation and characterization of polymer plasticized membranes (PPM) embedding a crown ether carrier application to copper ions transport. Mat. Sci. Eng. C 2005, 25, 436-443. [CrossRef]

41. Arous, O.; Kerdjoudj, H.; Seta, P. Comparison of carrier-facilitated silver(I) and copper(II) ions transport mechanisms in a supported and in a plasticized cellulose triacetate membrane. J. Membr. Sci. 2004, 241, 177-185. [CrossRef] 
42. Radzyminska-Lenarcik, E.; Ulewicz, M. The application of polymer inclusion membranes based on CTA with 1-alkylimidazole for the separation of zinc(II) and manganese(II) ions from aqueous solutions. Polymers 2019, 11, 242. [CrossRef] [PubMed]

43. Gardner, J.S.; Walker, J.O.; Lamb, J.D. Permeability and durability effects of cellulose polymer variation in polymer inclusion membranes. J. Membr. Sci. 2004, 229, 87-93. [CrossRef]

44. Pernak, J.; Krysinski, J.; Skrzypczak, A. Bakterizide wirkung von iminiumverbindungen. A Tenside Surfact Det. 1987, 27, 276-286.

45. Lenarcik, B.; Ojczenasz, P. The influence of the size and position of the alkyl groups in alkylimidazole molecules on their acid - base properties. J. Heterocycl. Chem. 2002, 39, 287-290. [CrossRef]

46. Ulewicz, M.; Radzyminska-Lenarcik, E. Supported liquid (SLM) and polymer inclusion (PIM) membranes pertraction of copper(II) from aqueous nitrate solutions by 1-hexyl-2-methylimidazole. Sep. Sci. Technol. 2012, 47, 1383-1389. [CrossRef]

47. Radzyminska-Lenarcik, E.; Ulewicz, M. The use of 1-alkylimidazoles for selective separation of zinc ions in the transport process across polymer inclusion membrane. Physicochem. Probl. Miner. Process. 2014, 50, 131-142.

48. Ulewicz, M.; Sadowska, K.; Biernat, J.F. Selective transport of $\mathrm{Pb}(\mathrm{II})$ across polymer inclusion membrane using imidazole azocrown ethers as carriers. Physicochem. Probl. Miner. Process. 2007, 41, 133-143.

49. Ulewicz, M.; Szczygelska-Tao, J.; Biernat, J.F. Selectivity of $\mathrm{Pb}$ (II) transport across polymer inclusion membranes doped with imidazole azothiacrown ethers. J. Membr. Sci. 2009, 344, 32-38. [CrossRef]

50. Salazar-Alvarez, G.; Bautista-Flores, A.N.; San Miguel, E.R.; Muhammed, M.; Gyves, J. Transport characterization of a PIM system used for the extraction of $\mathrm{Pb}(\mathrm{II})$ using D2EHPA as carrier. J. Membr. Sci. 2005, 250, 247-257. [CrossRef]

51. Tor, A.; Arslan, G.; Muslu, H.; Celikas, A.; Cengeloglu, Y.; Ersoz, M. Facilitated transport of Cr(III) thought polymer inclusion membrane with di(2-ethylhexyl) phosphoric acid (DEHPA). J. Membr. Sci. 2009, 329, 169-174. [CrossRef]

52. Danesi, P.R. Separation of metal species by supported liquid membranes. Sep. Sci. Technol. 1984, 19, 857-894. [CrossRef]

53. Radzyminska-Lenarcik, E.; Witt, K. The application of membrane extraction on the separation of zinc and cadmium ions. Desalin. Water Treat. 2018, 128, 140-147. [CrossRef]

54. Wolf, J.R.; Strieder, W. Surface and void tortuosities for a random fiber bed: Overlapping, parallel cylinders of several radii. J. Membr. Sci. 1990, 49, 103-115. [CrossRef]

55. Lenarcik, B.; Kierzkowska, A. The influence of alkyl chain length and steric effect on extraction of zinc(II) complexes with 1-alkyl-2-methylimidazoles. Solvent Ext. Ion Exch. 2006, 24, 433-445. [CrossRef]

56. Radzyminska-Lenarcik, E.; Lenarcik, B. Determination of stability constants of some 1-Alkylimidazole complexes with Cd(II) by extraction method. In Proceedings of the XXIVth International Symposium on Physicochemical Methods of Separations “Ars Separatoria 2009”, Kudowa-Zdroj, Poland, 14-18 June 2009; pp. 187-188.

57. Lenarcik, B.; Rauckyte, T. The influence of alkyl chain length on extraction equilibria of Ni(II) complexes with 1-alkylimidazoles in aqueous solution/organic solvent systems. Sep. Sci. Technol. 2004, 39, 3353-3372. [CrossRef]

58. Lenarcik, B.; Kierzkowska, A. The influence of alkyl chain length on stability Constants of Zn(II) Complexes with 1-Alkylimidazoles in Aqueous Solutions and their partition between aqueous phase and organic solvent. Solvent Ext. Ion Exch. 2004, 22, 449-471. [CrossRef]

59. Lenarcik, B.; Adach, A.; Radzyminska-Lenarcik, E. The influence of steric effect and alkyl chain length on the extraction of the complexes of $\mathrm{Co}(\mathrm{II}), \mathrm{Ni}(\mathrm{II}), \mathrm{Cu}(\mathrm{II}) \mathrm{Zn}(\mathrm{II})$ and $\mathrm{Cd}(\mathrm{II})$ with 1-alkyl-2-methylimidazole. Pol. J. Chem. 1999, 73, 1273-1281.

60. Radzyminska-Lenarcik, E. Search for the possibility of utilizing the differences in complex-forming capacities of alkylimidazoles for selective extraction of some metal ions from aqueous solutions. Pol. J. Chem. Technol. 2008, 10, 73-78. [CrossRef]

61. Lenarcik, B.; Kierzkowska, A. The influence of alkyl chain length and steric effect on stability constants and extractability of Zn(II) complexes with 1-alkyl-4-methylimidazoles. Solv. Ext. Ion Exch. 2004, 39, 3485-3508. [CrossRef] 
62. Lenarcik, B.; Kurdziel, K.; Czopek, R. Search for optimum conditions of extraction of metal complexes with alkylimidazoles. III. Structure-extractability relationships for 1,4-dimethylimidazole complexes of Co(II), $\mathrm{Ni}(\mathrm{II}), \mathrm{Cu}(\mathrm{II}), \mathrm{Zn}(\mathrm{II})$, and Cd(II). Solvent Ext. Ion Exch. 1986, 4, 165-182. [CrossRef]

63. Radzyminska-Lenarcik, E.; Witt, K. Studies on the separation of some transition metals using trialkylimidazole as selective extractant. In Proceedings of the E3S Web of Conferences, MEC2017, Wisła, Poland, 20-23 September 2017; Volume 18, p. 01017.

64. Ulewicz, M.; Walkowiak, W.; Gega, J.; Pospiech, B. Zinc(II) selective removal from other transition metal ions by solvent extraction and transport through polymer inclusion membranes with D2EHPA. Ars Sep. Acta 2003, 2, 47-55.

65. Ulewicz, M.; Walkowiak, W. Selective removal of transition metal ions by transport through polymer inclusion membranes with organophosphous acids. Environ. Prot. Eng. 2005, 31, 73-81.

66. Kozlowska, J.; Kozlowski, C.; Koziol, J.J. Transport of Zn(II), Cd(II), and Pb(II) cross CTA plasticized membranes containing organophosphorous acids as ion carriers. Sep. Purif. Technol. 2007, 57, 430-434. [CrossRef]

67. Kozlowski, C.A.; Girek, T.; Walkowiak, W.; Koziol, J.J. Application of hydrophobic â-cyclodextrin polymer in separation of metal ions by plasticized membranes. Sep. Purif. Technol. 2005, 46, 136-144. [CrossRef]

68. Kozlowski, C.A.; Kozlowska, J. PNP-16-crown-6 derivatives as ion carriers for $\mathrm{Zn}(\mathrm{II}), \mathrm{Cd}(\mathrm{II})$ and $\mathrm{Pb}$ (II) transport across polymer inclusion membranes. J. Membr. Sci. 2009, 326, 215-221. [CrossRef]

69. Kozłowski, C.; Walkowiak, W. Transport of $\mathrm{Cr}(\mathrm{VI}), \mathrm{Zn}(\mathrm{II})$ and $\mathrm{Cd}(\mathrm{II})$ ions across polymer inclusion membranes with tridecyl(pyridine) oxide and tri-n-octylamine. Sep. Sci. Technol. 2004, 39, 3127-3141. [CrossRef]

70. Alguacil, F.J.; Alonso, M. Separation of zinc(II) from cobalt(II) solutions using supported liquid membrane with DP-8R as a carrier. Sep. Purif. Technol. 2005, 41, 179-184. [CrossRef]

71. Rehman, H.U.; Akhtar, G.; Rashid, H.U.; Ali, N.; Ahmad, I.; Rehman, S.U.; Khan, K.; Arshad, M. Transport of Zn (II) by TDDA-Polypropylene Supported Liquid Membranes and Recovery from Waste Discharge Liquor of Galvanizing Plant of Zn (II). J. Chem. 2017, 2017, 7569354. [CrossRef]

(C) 2019 by the authors. Licensee MDPI, Basel, Switzerland. This article is an open access article distributed under the terms and conditions of the Creative Commons Attribution (CC BY) license (http://creativecommons.org/licenses/by/4.0/). 